\title{
MOLECULAR CHARACTERISATION OF EXTENDED-SPECTRUM $\beta$ - LACTAMASE-PRODUCING ESCHERICHIA COLI AND SALMONELLA ISOLATED FROM POULTRY AND POULTRY PRODUCTS IN EGYPT
}

\author{
N. M. KAMEL ${ }^{1}$, E. M. FARGHALY ${ }^{1}$, H. M. SHAWKY ${ }^{2}$ \& A. SAMIR ${ }^{2}$ \\ ${ }^{1}$ Reference Laboratory for Veterinary Quality Control on Poultry Production, \\ Animal Health Research Institute, Dokki, Giza, Egypt; ${ }^{2}$ Microbiology De- \\ partment, Faculty of Veterinary Medicine, Cairo University, Giza, Egypt
}

\section{Summary}

Kamel, N. M., E. M. Farghaly, H. M. Shawky \& A. Samir, 2021. Molecular characterisation of extended-spectrum $\beta$-lactamase-producing Escherichia coli and Salmonella isolated from poultry and poultry products in Egypt. Bulg. J. Vet. Med., 24, No 1, 43-56.

Extended-spectrum $\beta$-lactamase (ESBL) producing E. coli and salmonellae have spread rapidly worldwide and pose a serious threat to human and animal health. The present study was conducted to determine the prevalence of ESBL-producing E.coli and salmonellae, to perform molecular characterisation of the ESBL-related bla genes, including $b l a_{\mathrm{TEM}}, b l a_{\mathrm{SHV}}$ and $b l a_{\mathrm{CTX}}$, and the susceptibilities of these bacteria to various antimicrobial agents. From a total of 300 poultry samples, 25 and 20 samples were recognised as Salmonella and E. coli, respectively by microbiological and molecular methods. All E. coli and Salmonella isolates were positive for an ESBL phenotype. Molecular detection for antibiotic resistance gene revealed $b l a_{\mathrm{TEM}}$ in all isolates of salmonellae and E. coli $(100 \%)$, while $b l a_{\mathrm{SHV}}$ was detected in $5(20 \%)$ and $2(10 \%)$ of salmonellae and E. coli isolates, respectively. None of the isolates contained bla $a_{\mathrm{CTX}}$ gene. Serotyping of Salmonella spp. in chickens revealed that $S$. enteritidis was the major isolates followed by $S$. Infantis $(21.4 \%), S$. Kentucky (14.2\%) and $S$. Typhimurium, $S$. Kapemba, $S$. Newport, $S$. Vejle and $S$. Magherafelt were detected at $7.1 \%$ respectively. $S$. Infantis was the major isolate detected in chicks $(60 \%)$, while in ducks $S$. Typhimurium and $S$. Blegdam were identified. In ducklings, $S$. Sinchew, $S$. Infantis and $S$. Sekondi were equally prevalent. Only $S$. Newmexico was identified in poultry products. $E$. coli in chicken were serotyped into O1, O8, O29, O125, O128 and O157. In chicks, O29 and O126 serotypes were detected. In poultry products only O8 was detected. The results indicate that ESBL frequency has reached an alarming level in poultry isolates in Egypt, with TEM enzymes being the predominant $\beta$-lactamases detected.

Key words: E. coli, ESBL, poultry, poultry products, Salmonella

\section{INTRODUCTION}

Poultry industry is one of the most widespread food industries worldwide. Chicken is the most commonly farmed species, with over 90 billion tons of chicken meat produced per year (FAO, 2017). However, there is a potential threat 
of bacterial infection to poultry that can result in a huge economic loss. A lot of antimicrobials are used to raise poultry in most countries (Landers et al., 2012). The same antimicrobials are considered to be essential in human medicine (WHO, 2010). The misuse of such essential antimicrobials in animal production is likely to accelerate the development of antibiotic resistance in pathogens, as well as in commensal organisms.

$E$. coli is commonly found in human and animal intestinal tracts and, as a result of faecal contamination or contamination during food animal slaughter, is often found in soil, water, and foods. A number of $E$. coli strains are recognised as important pathogens of colibacillosis in poultry and some of them can cause severe human diseases such as haemorrhagic colitis and haemolytic uremic syndrome (Ferens \& Hovde, 2011). This reservoir of E. coli has a zoonotic potential that could be transferred directly from poultry to humans (Ewers et al., 2009).

Salmonella infections are a major public health problem with a significant social and economic impact. Many animal species are potential reservoirs for this bacterium, especially chickens, pigeons and reptiles (Sanchez et al., 2002). Salmonella spp. is widespread in poultry production. Prevalence varies depending on country and type of production as well as the detection methods applied. It is known to be the etiological agent of salmonellosis in both humans and animals. Food-borne salmonellosis still occurs throughout the world (Bell \& Kyriakides, 2007).

The use of antibiotics in animals (Mahbub et al., 2011) and poultry feed (Diarra et al., 2007) disrupts normal flora of intestine, resulting in emergence of antibiotic-resistant salmonellae and E. coli which then find their way into the envi- ronment and food chain. Increasing resistance to antimicrobial agents remains a major challenge to public health professionals in both developed and developing countries. However, antimicrobial resistance is exacerbated by over-prescription of antibiotics and increased use in both human and animal healthcare (Da Costa et al., 2013). Drug resistance is growing and has affected critically important classes of antibiotics, such as the $\beta$-lactams, which are among the most significant bactericidal antibiotics used to treat bacterial infections in humans (Livermore et al., 2007).

Extended spectrum beta-lactamases (ESBLs) are enzymes produced by certain bacteria that are able to hydrolyse extended spectrum cephalosporins. They are effective against beta-lactam antibiotics such as ceftazidime, ceftriaxone, cefotaxime and oxyiminomonobactam. Globally, ESBLs are considered to be problematic and there is an increasing frequency of ESBL in different parts of the world (Ghafourian et al., 2014). In veterinary medicine, a variety of these drugs is currently authorised for use, resulting in the emergence of ESBL-producing Gramnegative bacteria (Bush et al., 1995). ESBL Enterobacteriaceae are widespread in poultry farming, but were also detected in other farm animals and their meat products (Doi et al., 2010).

TEM, SHV and CTX-M are the most prevalent ESBL types (Cantón \& Coque, 2006). The presence of ESBL genes has been clearly reported in food-production animals and the food chain has been described as a possible pathway from animals to humans (Leverstein-van Hall et al., 2011). ESBL producing bacteria have been recovered from livestock (swine, cattle, poultry, and turkey), from companion animals (cats, dogs, horses), and from wild animals. The gastrointestinal 
tract of animals is a reservoir for bacteria carrying $\beta$-lactamases and a potential source of human pathogens. In particular, ESBL has been described in healthy poultry, in faecal samples of broilers and in broiler chicken caecal samples and turkey flocks (Bortoloaia et al., 2011).

The occurrence of antibiotic-resistant bacteria and the presence of such bacteria on poultry farms in any country is of global significance because of the possibility of their local or even worldwide spreading by humans, animals, insect vectors, agricultural products, food products or surface water (Davies \& Davies, 2010). Therefore, it is very important to monitor the resistance to antibiotics not only in human bacterial pathogens but also in pathogenic and commensal bacteria of animal origin. The aim of present study was to determine the prevalence of ESBL-producing E. coli and Salmonella and molecular characterisation of the ESBL-related bla genes, including $b l a_{\mathrm{TEM}}, b l a_{\mathrm{SHV}}$ and $b l a_{\mathrm{CTX}}$ in poultry and poultry products.

\section{MATERIALS AND METHODS}

\section{Samples}

A total number of 300 samples - 250 from different poultry organs (liver, lung, heart, intestine, yolk sac and meconium of chickens $(n=120)$, ducks $(n=40)$, chicks $(\mathrm{n}=30)$, turkeys $(\mathrm{n}=30)$ turkey poults $(\mathrm{n}=20)$, ducklings $(\mathrm{n}=10)$ as well as 50 samples from poultry products (fillets, nuggets, shawarma, chicken luncheon and chicken stoke cubes) were collected and tested for the presence of E. coli and salmonellae. The examined samples were collected under complete aseptic conditions using sterile scissor and forceps, with sterile sampling materials (bags, spatula) wearing disposable gloves and subjected to bacteriological examinations.

\section{Isolation of Salmonella species}

Samples were examined for the presence of Salmonella spp. according to ISO 6579:2002-COR 2004. Briefly $0.1 \mathrm{~mL}$ of pre-enriched culture was transferred to 9.9 $\mathrm{mL}$ Rappaport Vassilidis (RV) broth (CM0669, Oxoid) and incubated at $41^{\circ} \mathrm{C}$ for 18 to $24 \mathrm{~h}$, loopful from the selective enrichment broth being inoculated onto Xylose Lysine Deoxycholate (XLD) (CM0469, Oxoid) agar and incubated at $37{ }^{\circ} \mathrm{C}$ for 18 to $24 \mathrm{~h}$. The suspected isolates were stored on nutrient agar (CM0309, Oxoid) slant and kept at $4{ }^{\circ} \mathrm{C}$ for further identification by Gram's staining and other biochemical tests.

\section{Isolation of Escherichia coli}

A $0.1 \mathrm{~mL}$ aliquot from the pre-incubated samples in BPW was streaked onto MacConkey agar (CM0007, Oxoid) plates and incubated at $37{ }^{\circ} \mathrm{C}$ for $24 \mathrm{~h}$ according to Kreig et al. (1984). Typical E. coli colonies were subcultured in nutrient agar slant and incubated for $24 \mathrm{~h}$ at $37{ }^{\circ} \mathrm{C}$ then kept at $4{ }^{\circ} \mathrm{C}$ for further study.

\section{Serogrouping}

E. coli and salmonellae isolates were serotyped in the Reference Laboratory for Veterinary Quality Control on Poultry Production using commercially available kits (Test Sera Enteroclon, Anti-Coli, SIFIN Berlin, Germany,_ISO 6579:2002).

\section{Identification of ESBL producers}

ESBL-producing isolates were screened by a phenotypic confirmatory test using cefotaxime, ceftazidime, cefotaxime/clavulanate (2:1) and ceftazidime/clavulanate (2:1) according to Clinical and Laboratory Standard Institute (CLSI, 2007). All 
ESBL-producing isolates were collected for further investigation.

\section{Antimicrobial susceptibility test}

Antibiotic sensitivity was performed using Mueller Hinton Agar plates (HIMEDIA) using antibiotic discs of 15 commonly used chemotherapeutic agents. Interpretation of the results based on the diameter of the inhibition zones produced was done according to CLSI (2017). Isolates shown to be resistant to at least three different classes of agent were classified as multidrug resistant (MDR) (Kiratisin et al., 2008).

\section{Molecular identification}

Extraction of DNA was done according to instructions for use of QIAamp DNA mini kit (Catalogue no.513). Briefly, $200 \mu \mathrm{L}$ of the sample was added to $20 \mu \mathrm{L}$ of proteinase $\mathrm{K}$ and $200 \mu \mathrm{L}$ of AL lysis buffer and incubated at $56{ }^{\circ} \mathrm{C}$ for $10 \mathrm{~min}$ in a BiometraTsc thermal block. After incubation, $200 \mu \mathrm{L}$ of $100 \%$ ethanol was added to the lysate and vortexed. The sample was then washed twice and centrifuged according to the manufacturer's instructions. DNA was eluted with $100 \mu \mathrm{L}$ of elution buffer supplied in the kit.

Oligonucleotide primers used in PCR were supplied from Metabion (Germany) and Biobasic (Canada) (Table 1). The 25- $\mu \mathrm{L}$ master mix contained $12.5 \mu \mathrm{L}$ of Emerald Amp Max PCR Master Mix (Takara, Japan), $1 \mu \mathrm{L}$ of 20 pmol of each primer, $4.5 \mu \mathrm{L}$ of water, and $6 \mu \mathrm{L}$ of template DNA. The reactions were performed in Applied Biosystem 2720 thermal cyclers.

Fifteen microliters of each PCR product were loaded in each gel lane of $1.5 \%$ agarose gel (Applichem). Electrophoresis was done in $1 \times$ TBE (Tris Boric acid EDTA) buffer using $5 \mathrm{~V} / \mathrm{cm}$ gradients. A 100 bp DNA ladder (Fermentas) was used to determine the fragment sizes. The PCR photos were photographed and analysed by using a gel documentation system (Alpha Innotech, Biometra, Germany) through its computer software.

\section{RESULTS}

Poultry and poultry products samples were examined for the presence of Salmonella and E. coli. Out of the total 300 samples, 25 Salmonella strains and 20 E. coli strains were detected. Three poultry products of all analysed poultry products resulted as two positive for E. coli and one positive for Salmonella.

The results of Salmonella serotyping are listed in Table 2. Twenty-five Salmonella isolates was serotyped into different serotypes. In chickens 14 serotypes were identified and $S$. Enteritidis was the most

Table 1. Oligonucleotide primers sequences sources

\begin{tabular}{|c|c|c|c|c|}
\hline $\begin{array}{l}\text { Microbial } \\
\text { agent }\end{array}$ & Gene & Primer sequence $\left(5^{\prime}-3^{\prime}\right)$ & $\begin{array}{l}\text { Length of } \\
\text { amplified } \\
\text { product }\end{array}$ & Reference \\
\hline \multirow[t]{3}{*}{$\begin{array}{l}\text { E. coli, } \\
\text { Salmonella }\end{array}$} & $b l a_{\mathrm{TEM}}$ & $\begin{array}{l}\mathrm{F}: A T C A G C A A T A A A C C A G C \\
\text { R:CCCCGAAGAACGTTTTC }\end{array}$ & $516 \mathrm{bp}$ & $\begin{array}{l}\text { Colom et al., } \\
2003\end{array}$ \\
\hline & $b l a_{\mathrm{SHV}}$ & $\begin{array}{l}\text { F:AGGATTGACTGCCTTTTTG } \\
\text { R:ATTTGCTGATTTCGCTCG }\end{array}$ & $392 \mathrm{bp}$ & \\
\hline & $b l a_{\text {СТХ }}$ & $\begin{array}{l}\text { F:ATGTGCAGYACCAGTAARGTKAT } \\
\text { GGC } \\
\text { R:TGGGTRAARTARGTSACCAGAAY } \\
\text { CAGCGG }\end{array}$ & $593 \mathrm{bp}$ & $\begin{array}{l}\text { Archambault } \\
\text { et al., } 2006\end{array}$ \\
\hline
\end{tabular}


Table 2. Serogrouping of the isolated salmonellae

\begin{tabular}{|c|c|c|c|}
\hline Examined sample & Sero grouping & Number & Percentage \\
\hline \multirow[t]{8}{*}{ Chickens $(\mathrm{n}=14)$} & $S$. Enteritidis & 4 & $28.6 \%$ \\
\hline & $S$. Infantis & 3 & $21.4 \%$ \\
\hline & $S$. Kentucky & 2 & $14.2 \%$ \\
\hline & $S$. Typhimurium & 1 & $7.1 \%$ \\
\hline & $S$. Kapemba & 1 & $7.1 \%$ \\
\hline & $S$. Newport & 1 & $7.1 \%$ \\
\hline & $S$. Vejle & 1 & $7.1 \%$ \\
\hline & $S$. Magherafelt & 1 & $7.1 \%$ \\
\hline \multirow[t]{3}{*}{ Chicks $(\mathrm{n}=5)$} & $S$. Infantis & 3 & $60 \%$ \\
\hline & $S$. Papuana & 1 & $20 \%$ \\
\hline & S. Rosenberg & 1 & $20 \%$ \\
\hline \multirow[t]{2}{*}{ Ducks ( $\mathrm{n}=2)$} & $S$. Typhimurium & 1 & $50 \%$ \\
\hline & $S$. Blegdam & 1 & $50 \%$ \\
\hline \multirow[t]{3}{*}{ Ducklings $(\mathrm{n}=3)$} & S. Sinchew & 1 & $33.3 \%$ \\
\hline & S. Infantis & 1 & $33.3 \%$ \\
\hline & S. Sekondi & 1 & $33.3 \%$ \\
\hline Poultry products: fillet $(\mathrm{n}=1)$ & $S$. Newmexico & 1 & $100 \%$ \\
\hline
\end{tabular}

Table 3. Serogrouping of the isolated E. coli

\begin{tabular}{llcc}
\hline Examined sample & Sero grouping & Number & Percentage \\
\hline Chickens $(\mathrm{n}=15)$ & O1 & 2 & $13.3 \%$ \\
& O8 & 3 & $25 \%$ \\
& O29 & 1 & $8.3 \%$ \\
& O125 & 1 & $8.3 \%$ \\
& O128 & 2 & $13.3 \%$ \\
& O157 & 1 & $8.3 \%$ \\
& Untypable & 5 & $41.7 \%$ \\
\hline Chicks (n=3) & O29 & 1 & $33.3 \%$ \\
& O126 & 1 & $33.3 \%$ \\
& Untypable & 1 & $33.3 \%$ \\
\hline Poultry products (fillet)(n=2) & O8 & 1 & $50 \%$ \\
& Untypable & 1 & $50 \%$ \\
\hline
\end{tabular}

predominant one while in chicks $S$. Infantis was the major isolate obtained. Another two serotypes were identified in ducks: $S$. Typhimurium and $S$. Blegdam but in ducklings three serotypes were identified: $S$. Sinchew, $S$. Infantis and $S$. Sekondi. Only $S$. Newmexico serotype was identified in poultry products (chicken fillet).
In the present study $20 \mathrm{E}$. coli was isolated out of total 300 examined samples (Table 3). Serotyping of the isolates by slide agglutination technique revealed the distribution of the detected isolates in different serotypes, $15 \mathrm{E}$. coli isolates from the chicken were serotyped into $\mathrm{O} 1$, O8, O29, O125, O128 and O157. In chicks two serotypes were detected: O29 
Molecular characterisation of extended-spectrum $\beta$-lactamase-producing Escherichia coli and ....

Table 4. Characteristics of ESBL-producing E.coli isolates recovered from poultry and poultry products

\begin{tabular}{llcc}
\hline Examined sample & Serotype & $\begin{array}{c}\text { Number of ESBL- } \\
\text { positive }\end{array}$ & $\begin{array}{c}\text { Number of } \\
\text { MDR-positive }\end{array}$ \\
\hline Chickens $(\mathrm{n}=15)$ & O1 $(\mathrm{n}=2)$ & 2 & 2 \\
& O8 $(\mathrm{n}=3)$ & 3 & 3 \\
& O29 $(\mathrm{n}=1)$ & 1 & 1 \\
& O125 $(\mathrm{n}=1)$ & 1 & 1 \\
& O128 $(\mathrm{n}=2)$ & 2 & 2 \\
& O157 $(\mathrm{n}=1)$ & 1 & 1 \\
& Untypable $(\mathrm{n}=5)$ & 5 & 4 \\
\hline Chicks $(\mathrm{n}=3)$ & O29 $(\mathrm{n}=1)$ & 1 & 1 \\
& O126 $(\mathrm{n}=1)$ & 1 & 1 \\
\hline Poultry products (fillet) $(\mathrm{n}=2)$ & Ontypable $(\mathrm{n}=1)$ & 1 & 1 \\
& O8 $(\mathrm{n}=1)$ & 1 & 1 \\
\hline
\end{tabular}

Table 5. Characteristics of ESBL-producing Salmonella isolates recovered from poultry and poultry products.

\begin{tabular}{|c|c|c|c|}
\hline Examined sample & Serotype & $\begin{array}{l}\text { Number of } \\
\text { ESBL-positive }\end{array}$ & $\begin{array}{c}\text { Number of } \\
\text { MDR-positive }\end{array}$ \\
\hline \multirow[t]{8}{*}{ Chickens $(\mathrm{n}=14)$} & $S$. Enteritidis $(\mathrm{n}=4)$ & 4 & 1 \\
\hline & $S$. Infantis $(\mathrm{n}=3)$ & 3 & 2 \\
\hline & $S$. Kentucky $(\mathrm{n}=2)$ & 2 & 1 \\
\hline & $S$. Typhimurium $(\mathrm{n}=1)$ & 1 & 1 \\
\hline & $S$. Kapemba $(\mathrm{n}=1)$ & 1 & - \\
\hline & $S$. Newport $(\mathrm{n}=1)$ & 1 & - \\
\hline & $S$. Vejle $(\mathrm{n}=1)$ & 2 & - \\
\hline & $S$. Magherafelt $(\mathrm{n}=1)$ & 1 & 1 \\
\hline \multirow[t]{3}{*}{ Chicks (n=5) } & $S$. Infantis $(\mathrm{n}=3)$ & 3 & 1 \\
\hline & S. Papuana $(\mathrm{n}=1)$ & 1 & 1 \\
\hline & $S$. Rosenberg $(\mathrm{n}=1)$ & 1 & - \\
\hline \multirow[t]{2}{*}{ Ducks $(\mathrm{n}=2)$} & $S$. Typhimurium $(\mathrm{n}=1)$ & 1 & - \\
\hline & $S$. Blegdam $(\mathrm{n}=1)$ & 1 & - \\
\hline \multirow[t]{3}{*}{ Ducklings $(\mathrm{n}=3)$} & S. Sinchew $(\mathrm{n}=1)$ & 1 & 1 \\
\hline & $S$. Infantis $(\mathrm{n}=1)$ & 1 & - \\
\hline & S. Sekondi $(\mathrm{n}=1)$ & 1 & \\
\hline Poultry products (fillet) $(\mathrm{n}=1)$ & S. Newmexico $(\mathrm{n}=1)$ & 1 & \\
\hline
\end{tabular}

and O126. Only O8 was detected in poultry product.

Phenotypical detection of ESBL showed that all Salmonella and E.coli isolates were positive for ESBL producing. In addition some of the ESBL-producing strains expressed an MDR phenotype (Table 4 and 5).

Molecular characterisation of ESBL genes in Salmonella and E.coli strains revealed that all were ESBL phenotypepositive. All isolates of Salmonella and 


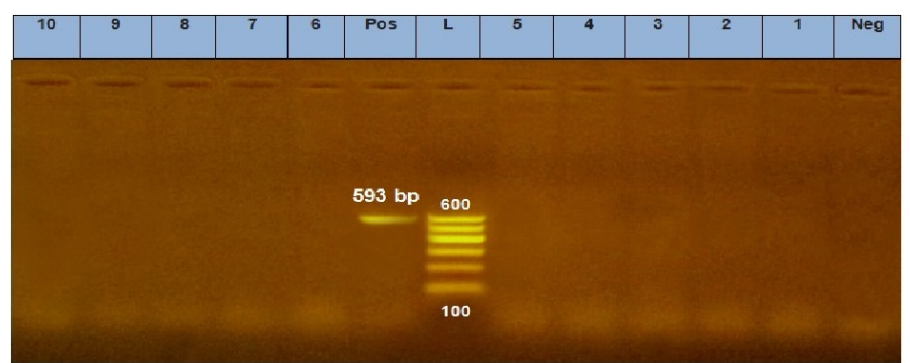

Fig. 1. Agarose gel electrophoresis of PCR for detection of bla $a_{\mathrm{CTX}}$ gene in Salmonella showing amplification of 593 bp in 25 examined samples. L (Ladder): DNA ladder (100-600 bp);

Lanes 1-10: negative samples; Pos: positive control; Neg: negative control.

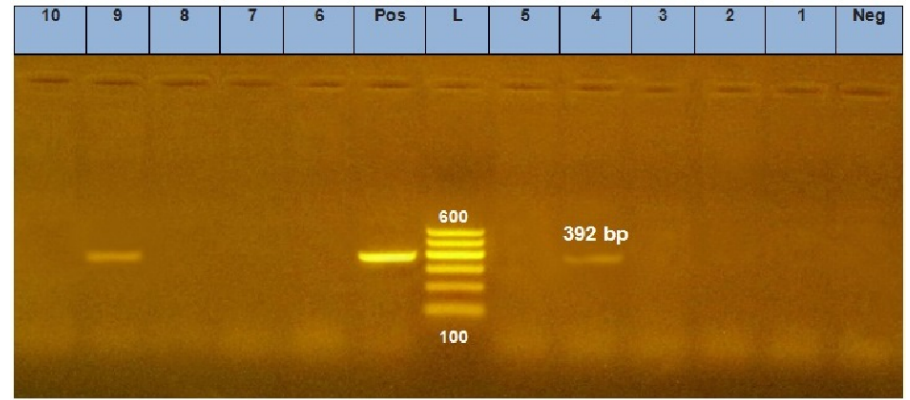

Fig. 2. Agarose gel electrophoresis of PCR for detection of $b l a_{\mathrm{SHV}}$ gene in E.coli showing amplification of 392 bp in 20 examined samples. L (Ladder): DNA ladder (100-600 bp); Lanes 4, 9: positive samples. Pos: positive control; Neg: negative control.

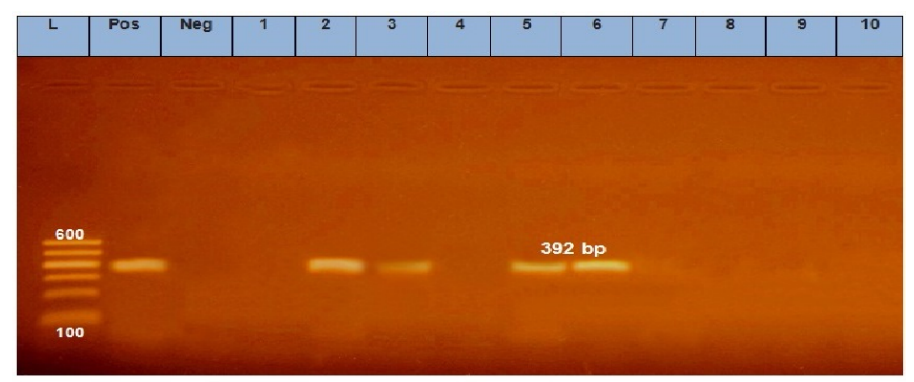

Fig. 3. Agarose gel electrophoresis of PCR for detection of blaSHVgene in Salmonella showing amplification of $516 \mathrm{bp}$ in examined samples. L (Ladder): DNA ladder (100-600 bp);

Lanes 2-6: positive samples. Pos: positive control; Neg: negative control.

E.coli carried the bla $a_{\mathrm{TEM}}$ gene while $b l a_{\mathrm{SHV}}$ was detected in $5(20 \%)$ Salmonella isolates and $2(10 \%) E$. coli isolates.
No bla $a_{\text {CTX }}$ was detected in salmonellae and E. coli (Fig 1-5). 


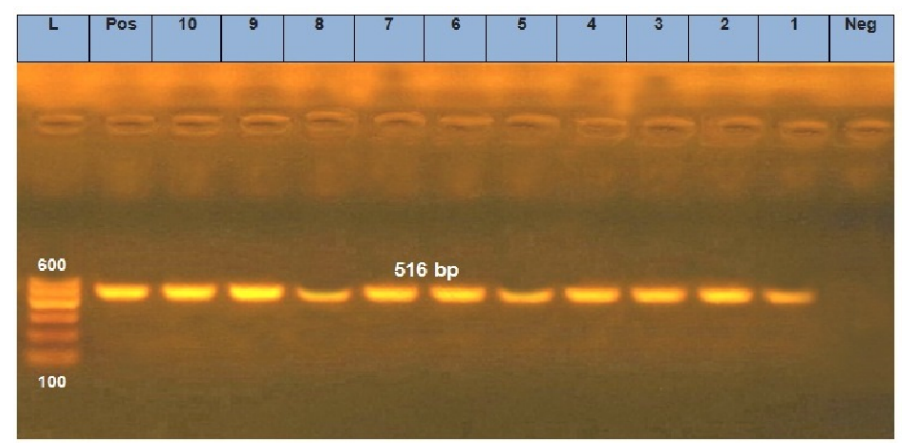

Fig. 4. Agarose gel electrophoresis of PCR for detection of bla TEM gene in Salmonella showing amplification of 516 bp. in examined samples. L (Ladder): DNA ladder (100-600 bp); Lanes 1-10: positive samples; Pos: positive control; Neg: negative control.

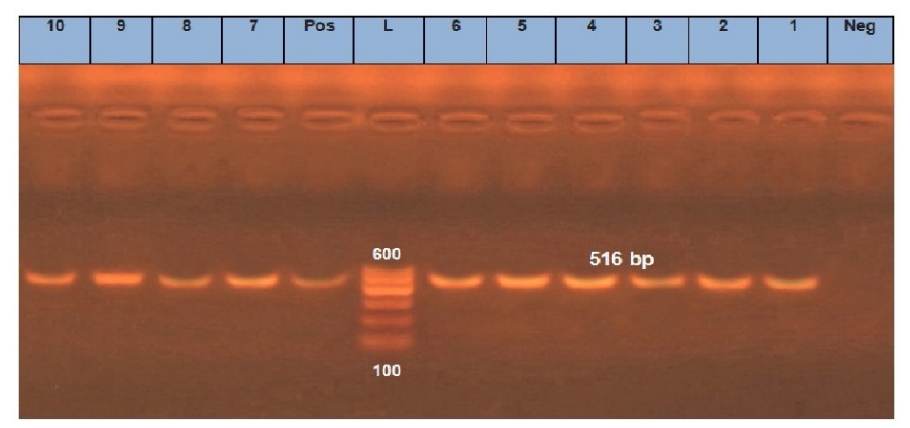

Fig. 5. Agarose gel electrophoresis of PCR for detection of bla ${ }_{T E M}$ gene in E.coli. Showing amplification of 516 bp. in examined samples. L (Ladder): DNA ladder (100-600 bp);

Lanes (1-10: positive samples; Pos: positive control; Neg: negative control.

\section{DISCUSSION}

Great attention has been paid to bacterial resistance to antibiotics in both human and animal populations for its adverse impacts on morbidity and mortality from diseases caused by resistant bacteria, economic costs of therapy and real risks of the spread of resistant strains among animals and humans (White, 2006). With the extensive use in poultry of $\beta$-lactam antibiotics such as amoxicillin and cephalosporins, especially extended-spectrum cephalosporins, ESBL-mediated resistance in Gram-negative bacilli has become increasingly critical, and therapeutic options for such infections - limited (Pfaller \& Segreti, 2006). It is important to detect ESBL producers in order to know the ESBL prevalence in animal-associated bacteria and to limit the spread of these MDR organisms in veterinary settings (Liu et al., 2007).

Salmonella infections are a major public health problem with a significant social and economic impact. Many animal species are potential reservoirs for this bacterium, especially chickens, pigeons and reptiles (Sanchez et al., 2002). Chickens and chicken products played an important 
role in Salmonella contamination and are considered the main cause of salmonellosis that causes enteritis in human beings. Moreover, the most important source for Salmonella infection in humans is handling poultry carcasses as well as consumption of undercooked poultry meat (Panisello et al., 2000).

In the present study Salmonella isolates are classified into different serotypes with variation in the percentage. This variation in result may be attributed to different breeds of chickens, different ages, and collection of samples during different seasons. Twenty five distinct Salmonella serotypes were identified; $S$. Enteritidis was the most frequent isolates in chicken, while in chicks $S$. Infantis was the major isolates. Also two other serotypes were identified in ducks: $S$. Typhimurium and $S$. Blegdam. In ducklings, three different serotypes were identified: $S$. Sinchew, $S$. Infantis, $S$. Sekondi and only $S$. Newmexico was detected in poultry product. Our data are similar to those of Ammar et al. (2010) who isolated $S$. Enteritidis from broiler chicken and chicken meat from Egypt. Hugo \& Russel (1998) reported that Salmonella spp. were isolated from poultry in Brazil with a prevalence of $2.7 \%$ and the most common isolates were $S$. Enteritidis $(48.8 \%), S$. Infantis (7.6\%), S. Typhimurium (7.2\%), and $S$. Heidelberg (6.4\%). Gwida \& ElGohary (2015) isolated $S$. Kentucky at high rate followed by $S$. Enteritidis, $S$. Infantis and $S$. Typhimurium. The association of specific serotypes with poultry might be related to host adaptation or other unknown factors (Uzzau et al., 2000).

$E$. coli is one of the most common causes of infection by Gram negative bacteria (Diekema et al., 1999). Avian pathogenic $E$. coli is responsible for causing colisepticaemia, coligranuloma and air sacculitis (Sams, 2001). In the current study serotyping of the obtained $E$. coli isolates revealed that $\mathrm{O} 8$ serotype was the predominant one. Our finding disagree with that of Eid et al. (2015) who reported that $\mathrm{O} 27$ was the predominant $E$. coli serotypes at a rate of $22 \%$ among the 13 identified serotypes. From the other hand serotyping of E.coli with the available kits failed to identify 7 isolates in this study. This finding agreed with that of Rosario et al. (2004) who failed to identify the serogroups of $15 \%$ of isolates. Also Eid et al. (2015) failed to identify 5 (14\%) of the $E$. coli isolates. There were variations in the distribution of serotypes according to geographic regions. Many serotypes have been found less frequently, while some APEC do not belong to known serotypes or are untypeable (Swayne, 2013).

The high prevalence of ESBL-producing E. coli and Salmonella (100\%) in poultry and poultry products in this study was in accordance with another survey on E. coli ESBL producers in Egypt (Ghafourian et al., 2012) indicating that $38 \%$ of the $E$. coli tested positive for ESBLs. Similarly, in Netherlands Kola et al. (2012) found that $100 \%$ of conventional and $84 \%$ of organic samples were ESBL producers. In this study, Ziech et al. (2016) demonstrated multidrug resistance in $86 \%$ and ESBL activity in $45 \%$ of the Salmonella spp. isolated from the studied broiler processing plants. In this regard, ESBL contamination might occur during the rearing process, slaughtering or finally, through the environment (Stuart et al., 2012).

In fact, Gregova (2012) showed that the occurrence of ESBLs in poultry meat could be related to the environmental microbes of the slaughterhouse, to scalding, defeathering, and evisceration processes, and to transfer of bacteria from chickens 
because of the contact through water and incorrect cleaning and disinfection. In addition, some of the ESBL-producing strains expressed an MDR phenotype, suggesting that ESBL-producing isolates have probably acquired additional resistance genes. In order to gain a better understanding of their genetic relationships, further studies are needed to characterise the plasmids on which bla genes and other resistance genes are located.

Resistance to $\beta$-lactam antimicrobial agents in Gram-negative bacilli is primarily mediated by $\beta$-lactamases. Although a variety of $\beta$-lactamases has been described, the TEM, SHV and CTX enzymes are those most frequently observed among members of the family Enterobacteriaceae (Livermore, 1995). Extendedspectrum $\beta$-lactamases (ESBLs) are considered one of the most important resistance mechanisms for penicillins and cephalosporins when these enzymes are produced in E. coli, Salmonella spp. and Klebsiella spp. (Bush, 2001).

A high incidence of $b l a_{\mathrm{TEM}}$ detection in E. coli and Salmonella $(100 \%)$ in the present study was previously recorded. Colom et al. (2003) detected bla $a_{\text {TEM }}$ gene in 45 out of $51(88.2 \%)$ amoxicillinclavulanate resistant $E$. coli isolates. Brinas et al. (2002) detected the bla $a_{\mathrm{TEM}}$ gene in $83 \%$ of 124 ampicillin resistant E. coli isolates including food isolates of chicken origin. Adelowo et al. (2014) found resistant genes in $E$. coli isolates from Nigeria and these included $b l a_{\text {TEM }}(85 \%)$. Ghazaei (2018) isolated 20 Salmonella strains from 100 samples of commercial broilers and spent hens among which $b a_{\mathrm{TEM}}$ was found to be the dominant $\beta$-lactamase gene $(85 \%)$, followed by bla $_{\text {СТХ-м }}(60 \%)$ and $b l a_{\mathrm{SHV}}(35 \%) ; 100 \%$ of the isolates were found to be ESBL producers. The low incidence of $b l a_{\mathrm{SHV}}$ in the present study is consistent with the report of Dandachi et al. (2018) who analysed 981 faecal swabs from 49 poultry farms in Lebanon. Out of 235 strains isolated, 217 were identified as E. coli $(92 \%)$. The putative TEM gene was detected in $83 \%$ of the isolates, SHV in $20 \%$, and CTX-M in $53 \%$. Yuan et al. (2009) performed molecular characterisation of ESBL and showed that none of the isolates contained the $b l a_{\mathrm{SHV}}$ gene. Our results disagree with those of Kar et al. (2015) who detected beta-lactamase genes in E.coli viz., bla $a_{\mathrm{SHV}}$ , bla $a_{\mathrm{CTX}-\mathrm{M}}$, bla $_{\mathrm{TEM}}$ and blaampC were detected in 17, 13, 9 and 2 isolates, respectively through PCR. The SHV was more prevalent than the other types of ESBLs in clinical isolates of bacteria (Jacoby, 1997).

None of the Salmonella and E. coli isolates carried the $b l a_{\text {CTх }}$ gene. These results disagree with Cantón \& Coque (2006) who mentioned that the main ESBL types were TEM, SHV, and CTXM. Rates of CTX-M infections have increased during the last decade compared with rates of TEM and SHV infections. Djeffal et al. (2017) reported that 18 of Salmonella strains (12 avian and 6 human) were found to produce ESBLs, identified as members of the blaCTX-M-1 $(n=12)$, blaCTX-M-15 $(n=5)$ and blaTEM group $(n=8)$. Two reasons for the absence of these genes might be the relatively small sample size and the exclusive origin of the poultry.

\section{CONCLUSION}

The findings from this work support the need for a critical review of the usage of antimicrobial agents in livestock in Egypt and the importance of taking specific steps to curtail the indiscriminate use of antimicrobial agents to prevent the possi- 
ble adverse consequences in animal production, as well as in humans. There is an urgent need to formulate a strategy and put the necessary plan in place to execute a policy targeted at the promotion of rational use of antimicrobial agents, as an important element in antimicrobial resistant containment.

\section{ACKNOWLEDGEMENTS}

The authors would like to acknowledge Heba Bader, Ahmed Sayed, Hend Karm and the staff of microbiology unit at Reference Laboratory of Poultry Production (RLQP) for their kind support.

\section{REFERENCES}

Ammar, A. M. A., Y. A. E. Ahmed, A. M. I. Asawy \& A. A. Ibrahim, 2009. Bacteriological studies on Salmonella enteritidis isolated from different sources in Dakhlia Governorate. Assiut Veterinary Medical Journal, 56, 125-135.

Archambault, M., P. Petrov, R.S. Hendriksen, G. Asseva, A. Bangtrakulnonth, H. Hasman \& F. M. Aarestrup, 2006. Molecular characterization and occurrence of extended-spectrum $\beta$-lactamase resistance genes among Salmonella enterica serovar Corvallis from Thailand, Bulgaria, and Denmark. Microbial Drug Resistance, 12, 192-198.

Bell, C. \& A. Kyriakides, 2007. Salmonella: A Practical Approach to the Organism and its Control in Foods. Oxford: Blackwell Science.

Bortolaia, V., J. Larsen, P. Damborg \& L. Guardabassi, 2011. Potential pathogenicity and host range of Extended-Spectrum $\beta$ Lactamase-producing Escherichia coli isolates from healthy poultry. Applied and Environmental Microbiology,77, 58305833.

Briñas, L., M. Zarazaga, Y. Sáenz, F. RuizLarrea \& C. Torres, 2002. $\beta$-lactamases in ampicillin-resistant Escherichia coli isolates from foods, humans, and healthy animals. Antimicrobial Agents and Chemotherapy, 46, 3156-3163.

Bush, K., G.A. Jacoby \& A. A. Medeiros, 1995. A functional classification scheme for beta-lactamases and its correlation with molecular structure. Antimicrobial Agents and Chemotherapy, 39, 1211-1233.

Bush, K., 2001. New $\beta$-lactamases in gramnegative bacteria: Diversity and impact on the selection of antimicrobial therapy. Clinical Infectious Diseases, 32, 10851089.

Cantón, R. \& T. M. Coque, 2006. The CTX-M $\beta$-lactamase pandemic. Current Opinion in Microbiology, 9, 466-475.

CLSI, 2007. Clinical and Laboratory Standard Institute. Performance Standards for Antimicrobial Susceptibility Testing; $17^{\text {th }} \mathrm{In}$ formational Supplement, M100-S17. Wayne, PA.

CLSI, 2017. Clinical and Laboratory Standard Institute. Performance Standards for Antimicrobial Susceptibility Testing; $20^{\text {th }}$ Informational Supplement. CLSI document M100-S20. CLSI, Wayne, PA.

Colom, K., J. Pérez, R. Alonso, A. FernándezAranguiz, E. Lariño \& R. Cisterna, 2003. Simple and reliable multiplex PCR assay for detection of bla TEM, bla SHV and bla OXA-1 genes in Enterobacteriaceae. FEMS Microbiology Letters, 223, 147151.

Da Costa P. M., L. Loureiro \& A. J. Matos, 2013. Transfer of multidrug-resistant bacteria between intermingled ecological niches: The interface between humans, animals and the environment. International Journal of Environmental Research Public Health, 10, 278-294.

Dandachi, I., E. S. Sokhn, E. A. Dahdouh, E. Azar, B. El-Bazzal, J. M. Rolain \& Z. Daoud, 2018. Prevalence and characterization of multi-drug-resistant gram-negative bacilli isolated from Lebanese poultry: A nationwide study. Frontiers in microbiology, $\mathbf{9}$, article 550 . 
Molecular characterisation of extended-spectrum $\beta$-lactamase-producing Escherichia coli and ....

Davies. J. \& D. Davies, 2010. Origins and evolution of antibiotic resistance. Microbiology and Molecular Biology Reviews, 74, 417-433.

Diarrassouba, F., M. S. Diarra, S. Bach, P. Delaquis, J. Pritchard, E. Topp \& B. J. Skura, 2007. Antibiotic resistance and virulence genes in commensal Escherichia coli and Salmonella isolates from commercial broiler chicken farms. Journal of food protection, 70, 1316-1327.

Diekema, D.J., M.A. Pfaller, R.N. Jones, G.V. Doern, P.L. Winokur, A.C. Gales, H.S. Sader, K. Kugler, M. Beach \& SENTRY Participants Group (Americas), 1999. Survey of bloodstream infections due to gramnegative bacilli: frequency of occurrence and antimicrobial susceptibility of isolates collected in the United States, Canada, and Latin America for the SENTRY Antimicrobial Surveillance Program, 1997. Clinical Infectious Diseases, 29, 595-607.

Djeffal, S., S. Bakour, B. Mamache, R. Elgroud, A. Agabou, S. Chabou, S. Hireche, O. Bouaziz, K.Rahal \& J.M. Rolain, 2017. Prevalence and clonal relationship of ESBL-producing Salmonella strains from humans and poultry in northeastern Algeria. BMC veterinary research, 13,132.

Doi, Y., D. L. Paterson, P. Egea, A. Pascual, L. López-Cerero, M. D. Navarro, J. M. Adams-Haduch, Z. A. Qureshi, H. E. Sidjabat \& J. Rodríguez-Baño, 2010. Extended-spectrum and CMY-type $\beta$ lactamase-producing Escherichia coli in clinical samples and retail meat from Pittsburgh, USA and Seville, Spain. Clinical Microbiology and Infection, 16, 33-38.

BIOHAZ, 2011. EFSA Panel on Biological Hazards. Scientific Opinion on an update on the present knowledge on the occurrence and control of foodborne viruses. EFSA Journal, 9, 2190.

Eid, S., S. A. Nasef \& A. M. Erfan, 2015. Multidrug resistant bacterial pathogens in eggs collected from backyard chickens. Assiut Veterinary Medical Journal, 61, 87-103.
Ewers, C., E. M. Antão, I. Diehl , H. C. Philipp \& L. H. Wieler, 2009. Intestine and environment of the chicken as reservoirs for extraintestinal pathogenic $E S$ cherichia coli strains with zoonotic potential. Applied and Environmenta Microbiology, 75, 184-192.

FAO, 2017. Food and Agricultural Organization Catalogue 2017. United Nations: Food and Agricultural Organization, http://www.fao.org/3/b-i6407e.pdf $\quad$ (14 April 2018 date last accessed).

Ferens, W. A. \& C. J. Hovde, 2011. Escherichia coli O157: H7: Animal reservoir and sources of human infection. Foodborne Pathogens and Disease, 8, 465487.

Ghafourian, S., Z. Sekawi, V. Neela, A. Khosravi, M. Rahbar \& N. Sadeghifard, 2012. Incidence of extended-spectrum betalactamase-producing Klebsiella pneumoniae in patients with urinary tract infection. Sao Paulo Medical Journal, 130, $37-43$.

Ghafourian, S., N. Sadeghifard, S. Soheili \& Z. Sekawi, 2014. Extended spectrum betalactamases: Definition, classification and epidemiology. Curr Issues Mol Biol, 17, 11-22.

Ghazaei, C., 2018. Phenotypic and molecular detection of $\beta$-lactamase genes $B L A$ tem, $B L A \mathrm{ctx}$, and BLAshv produced by Salmonella spp. isolated from poultry meat. Gene, Cell and Tissue, 5, e84367.

Gregova, G., M. Kmetova, V. Kmet, J. Venglovsky \& A. Feher, 2012. Antibiotic resistance of Escherichia coli isolated from a poultry slaughterhouse. Annals of Agricultural and Environmental Medicine, 19, 75-77.

Gwida, M. \& A. El-Gohary, 2015. Prevalence and characterization of antibiotic resistance food borne pathogens isolated from locally produced chicken raw meat and their handlers. Journal of Dairy, Veterinary \& Animal Research, 3, 00062. 
Hugo, W. B. \& A. D. Russel, 1998. Pharmaceutical Microbiology, $6^{\text {th }}$ edn, Blackwell Science Ltd., Oxford.

ISO, 2004. Microbiology of food and animal feeding stuffs. Horizontal methods for the detection and enumeration of Enterobacteriaceae. Part 2: colony-count method. ISO Norm 21528-2: 2004.

Jacoby, G. A., 1997. Extended-spectrum $\beta$ lactamases and other enzymes providing resistance to oxyimino- $\beta$-lactams. Infectious Disease Clinics of North America, 11, 875-887.

Kar, D., S. Bandyopadhyay, D. Bhattacharyya, I. Samanta, A. Mahanti \& P. K. Nanda, 2015. Molecular and phylogenetic characterization of multidrug resistant extended spectrum beta-lactamase producing Escherichia coli isolated from poultry and cattle in Odisha, India. Infection, Genetics and Evolution, 29, 82-90.

Kiratisin, P., A. Apisarnthanarak, C. Laesripa \& P. Saifon, 2008. Molecular characterization and epidemiology of extendedspectrum- $\beta$-lactamase-producing Escherichia coli and Klebsiella pneumoniae isolates causing health care-associated infection in Thailand, where the CTX-M family is endemic. Antimicrobial Agents and Chemotherapy, 52, 2818-2824.

Kola, A., C. Kohler, Y. Pfeifer, F. Schwab, K. Kühn, K. Schulz, V. Balau, K. Breitbach, A. Bast, W. Witte \& P. Gastmeier, 2012. High prevalence of extended-spectrum- $\beta$ lactamase-producing Enterobacteriaceae in organic and conventional retail chicken meat, Germany. Journal of Antimicrobial Chemotherapy, 67, 2631-2634.

Krieg, N. R. \& J. G. Holt, 1984. Bergey's Manual of Systematic Bacteriology, vol. 1. Williams and Wilkins. Baltimore London.

Landers, T. F., B. Cohen, T. E. Wittum \& E. L. Larson, 2012. A review of antibiotic use in food animals:Perspective, policy, and potential. Public Health Reports, 127, 4-22.

Leverstein-van Hall, M. A., C. M. Dierikx, J. Cohen Stuart Voets, M. P. Van Den
Munckhof, A. van Essen-Zandbergen, T. Platteel, A. C. Fluit, N. Van de SandeBruinsma, J. Scharinga \& M. J. M. Bonten, 2011. Dutch patients, retail chicken meat and poultry share the same ESBL genes, plasmids and strains. Clinical Microbiology and Infection, 17, 873-880.

Livermore, D. M., 1995. $\beta$-lactamase-mediated resistance and opportunities for its control. Journal of Antimicrobial Agents, 41, 2541.

Livermore, D. M., R. Canton, M. Gniadkowski, P. Nordmann, G. M. Rossolini, G. Arlet, J. Ayala, T. M. Coque, I. KernZdanowicz, F. Luzzaro \& L. Poirel, 2007. CTX-M: Changing the face of ESBLs in Europe. Journal of Antimicrobial Chemotherapy, 59, 165-174.

Liu, J. H., S. Y. Wei, J. Y. Ma, Z. L. Zeng, D. H. Lü, G. X. Yang \& Z. L. Chen, 2007. Detection and characterisation of CTX-M and CMY-2 $\beta$-lactamases among Escherichia coli isolates from farm animals in Guangdong Province of China. International Journal of Antimicrobial Agents, 29, 576-581.

Mahbub, K. R., M. M. Rahman \& M. M. Ahmed, 2011. Characterization of antibiotic resistant Salmonella spp isolated from chicken eggs of Dhaka city. Journal of Scientific Research, 3, 191-196.

Panisello, P. J., R. Rooney, P. C. Quantick \& R. Stanwell-Smith, 2000. Application of foodborne disease outbreak data in the development and maintenance of HACCP systems. International Journal of Food Microbiology, 59, 221-234.

Pfaller, M. A. \& J. Segreti, 2006. Overview of the epidemiological profile and laboratory detection of extended-spectrum $\beta$-lactamases. Clinical Infectious Diseases, 42, S153-S163.

Rosario, C. C., C. C. López, I. G. Tellez, O. A. Navarro, R. C. Anderson \& C. C. Eslava, 2004. Serotyping and virulence genes detection in Escherichia coli isolated from fertile and infertile eggs, dead-in-shell em- 
Molecular characterisation of extended-spectrum $\beta$-lactamase-producing Escherichia coli and ....

bryos, and chickens with yolk sac infection. Avian Diseases, 48, 791-802.

Sáenz, Y., M. Zarazaga, L. Briñas, M. Lantero, F. Ruiz-Larrea \& C. Torres, 2001. Antibiotic resistance in Escherichia coli isolates obtained from animals, foods and humans in Spain. International Journal of Antimicrobial Agents, 18, 353-358.

Sams, A. R., 2001. Poultry meat. In: Poultry Meat Processing and Quality, $1^{\text {st }}$ edn, CRC Press, Taylor \& Francis, New York.

Sanchez, S., C. L. Hofacre, M. D. Lee, J. J. Maurer \& M. P. Doyle, 2002. Animal sources of salmonellosis in humans. Journal of the American Veterinary Medical Association, 221, 492-497.

Uzzau, S., D. J. Brown, T. Wallis, S. Rubino, G. Leori, S. Bernard, J. Casadesus, D. J. Platt \& J. E. Olsen. 2000. Host-adapted serotypes of Salmonella enterica. Epidemiology \& Infection, 125, 229-255.

White, D. G., 2006. Antimicrobial resistance in pathogenic Escherichia coli from animals. In: Antimicrobial Resistance in Bacteria of Animal Origin, ed F. Aarestrup ASM Press, Washington, DC, pp. 145-166.

WHO, 2010. World Health Organization. WHO model list of essential medicines: $16^{\text {th }}$ list (updated), March 2010.

Yuan, L., J. H. Liu, G. Z. Hu, Y. S. Pan, Z. M. Liu, J. Mo \& Y. J. Wei, 2009. Molecular characterization of extended-spectrum $\beta$ lactamase-producing Escherichia coli isolates from chickens in Henan Province, China. Journal of Medical Microbiology, 58, 1449-1453.

Ziech, R. E., C. Lampugnani, A. P. Perin, M. J. Sereno, R. A. P. Sfaciotte, C. Viana, V. M. Soares, J. P. D. A. N. Pinto \& L. dos Santos Bersot, 2016. Multidrug resistance and ESBL-producing Salmonella spp. isolated from broiler processing plants. Brazilian Journal of Microbiology, 47, 191-195.

Paper received 05.06.2019; accepted for publication 13.08.2019

\section{Correspondence:}

Nesma Mohamed Kamel Ali

Reference Laboratory for Veterinary Quality Control on Poultry Production, Animal Health Research Institute, Nadi El-Seid St., P.O. Box 246, Dokki, Giza 12618, Egypt tel: +20201019836055 ; fax: +20233370957 , e-mail: nesmakamel1511@yahoo.com 